\title{
DESAIN TURBIN ANGIN POROS VERTIKAL UNTUK PENGGERAK POMPA AIR
}

\author{
Slamet Riyadi* dan Sendie Yuliarto Margen \\ Politeknik Baja Tegal Jalan Raya Barat Dukuhwaru, Slawi Kab. Tegal \\ Telp. (0283) 6196380. \\ Email: riyadislamet11@gmail.com
}

\begin{abstract}
Abstrak
Potensi energi angin di indonesia sangat melimpah. Sumber energi dari angin merupakan salah satu sumber energi bersih. Pengembangan turbin angin sangat sesuai dengan kondisi tersebut. Penelitian ini menggunakan metode eksperimental dengan menggunakan turbin angin vertical dengan jari-jari $70 \mathrm{~cm}$, tinggi $150 \mathrm{~cm}$, dengan dua buah sudu lebar $40 \mathrm{~cm}$. Untuk mempermudah dalam pengambilan data antara sudu dan lengan turbin di buat seperti sendi agar mudah untuk mengatur sudut sudu. Hasil data yang didapatkan dari penelitian ini adalah daya terbesar turbin angin poros vertikal yaitu 9,2 watt yang menghasilkan debit air sekitar 0,086 $\mathrm{m}^{3} / \mathrm{s}$, dengan daya teoretis 0,0002334 watt. Karakter dari turbin angin poros vertikal ini dapat berputar jika di kenai kecepatan angin yang rata-rata $3 \mathrm{~m} / \mathrm{s}$, sehingga turbin angin poros vertikal ini membutuhkan tempat yang lapang atau tinggi untuk mendapatkan hasil yang lebih maksimal sehingga sudu dapat berputar dengan baik pula. Dalam pengambilan data mencari debit air yang maksimum dari pengujian kecepatan angin 1 s/d 4 $\mathrm{m} / \mathrm{s}$ diperoleh debit air yng paling tinggi.
\end{abstract}

Kata Kunci : debit air, pompa hidran, turbin angin.

\section{PENDAHULUAN}

Sepanjang sejarah manusia kemajuankemajuan besar dalam kebudayaan selalu diikuti oleh meningkatnya konsumsi energi. Peningkatan ini berhubungan langsung dengan tingkat kehidupan penduduk serta kemajuan industrialisasi. Sejak revolusi industri, penggunaan bahan bakar meningkat secara tajam, oleh karena itu diperlukan sumber energi yang memenuhi semua kebutuhan. Salah satu sumber energi yang banyak digunakan adalah energi fosil. Sayangnya energi ini termasuk energi yang tidak dapat di perbaharui dan jika energi fosil ini habis maka di perlukan sumbersumber energi baru (Daryanto, 2007).

Untuk mengatasi ketergangguan terhadap energi fosil, maka perlu dilakukan konversi, konservasi, dan pengembangan sumber-sumber energi terbarukan. Pengembangan ini harus memperhatikan tiga "E" yaitu energi, ekonomi, dan ekologi. Jadi, pengembangan sumber energi harus dapat memproduksi energi dalam jumlah yang besar, dengan biaya yang rendah serta mempunyai dampak minimum terhadap lingkungan (Clup, 1991). Berbagai pemanfaatan energi bersih adalah penggunaan gas alam. Misalnya dengan memanfaatkanya pada mesin bahan bakar ganda (Agung Nugroho, dkk., 2018) namun masih ada sisa polusi dalam pemanfaatan energi dari teknologi tersebut. Salah satu pemanfaatan energi terbarukan yang saat ini yang memiliki potensi besar untuk di kembangkan adalah energi angin.

Energi ini merupakan energi yang bersih dan dalam proses produksinya tidak mencemari lingkungan (Nakajima dan Ikeda, 2008). Energi angin merupakan sumber daya alam yang dapat diperoleh secara cuma-cuma yang jumlahnya melimpah dan terseianya terus menerus sepanjang tahun. Indonesia merupakaan negara kepulaun yang memiliki sekitar 17.500 pulau dengan panjang garis pantai lebih dari 81.290 $\mathrm{km}$. Indonesia memiliki memiliki potensi energi angin yang sangat besar sekitar 9,3 GW dan total kapasitas yang baru terpasang saat ini sekitar 0,5 MW (Daryanto, 2007).

Potensi energi angin di indonesia umumnya berkecepataan lebih dari 5 meter per detik (m/detik). Hasil pemetaan Lembaga Penerbangan dan Antariksa Nasional (Lapan) pada 120 lokasi menunjukaan, beberapa wilayah memiliki kecepataan angin di atas 5 $\mathrm{m} /$ detik, masing-masing Nusa Tenggara Timur, Nusa Tenggara Barat, Sulawesi Selatan Selatan dan Pantai Jawa. Adapun kecepatan angin 4 $\mathrm{m} /$ detik hingga $5 \mathrm{~m} /$ detik tergolong bersekala menengah dengan potensi skala menengah dengan potensi kapasitas 10-100 KW.

Dalam melakukan penelitian ini hanya terbatas pada beberapa hal diantaranya luas sudu telah ditetapkan sebesar 2,10 meter, 
putaran poros diukur dengan menggunakan Tachometer, tidak melihat bahan baku yang berpengaruh terhadap putaran, kincir yang digunakan adalah kincir angin tipe vertikal dengan dua sudu. Berdasarkan latar belakang yang telah di uraikan, permasalahan utama yang akan diungkap dalam penelitian ini :

Tujuan dari penelitian ini ada mengetahui debit yang akan di hasilkan oleh turbin angin poros vertical dan daya pompa maksimal yang akan dihasilkan oleh turbin angin poros vertical.

\section{LANDASAN TEORI}

Daya turbin angin adalah daya yang di bangkitkan oleh rotor turbin angin (rotor blade) akibat mendapatkan daya dari hembusan angin. Daya turbin angin tidak sama dengan daya angin dikarenakan daya turbin angin terpengaruh oleh koefisien daya. Koefisien daya adalah persentase daya terdapat pada angin yang di rubah ke dalam bentuk energi mekanik (Victor dan Benjamin, 1999).

$$
\begin{aligned}
& \mathrm{P}=\mathrm{Cp} \cdot 1 / 2 \cdot \mathrm{p} \cdot \mathrm{A} \cdot \mathrm{V}^{3} \\
& \text { Dimana }: \\
& \mathrm{P}=\text { Daya }(\text { watt }) \\
& \mathrm{CP}=\text { Koefisien daya } \\
& \mathrm{P}=\text { Kerapatan Udara }\left(\mathrm{kg} / \mathrm{m}^{3}\right) \\
& \mathrm{A}=\text { Area penangkapan angan }\left(\mathrm{m}^{2}\right) \\
& \mathrm{V}=\text { Kecepatan angin }(\mathrm{m} / \mathrm{s})
\end{aligned}
$$

Di dalam rangkaian turbin angin yang berputar selain terdapat bilangan $\mathrm{Cp}$ yang mempengaruhi sudu dalam menghasilkan daya. Coefisien $\mathrm{Cd}$ yang mempengaruhi sudu dalam menghasilkan daya. Coefisien of drag (cd) adalah koefisien dari daya tarik (drag). Cd pada dasarnya adalah kecenderungan suatu bentuk mempertahankan diri pada kondisi yang ada dari gaya geser atau gaya tekan yang timbul. $\mathrm{Cd}$ dapat berupa benda bergerak ke arah atau di dalam arah aliran fluida yang dapat berupa gas atau cair. Setiap benda mempunyai angka koefisien Cd yang berbeda-beda. Semakin halus dan bundar suatu benda maka Cd akan semakin kecil. Besar koefisien Cd tidak dipengaruhi oleh ukuran dari benda namun dari sudut posisi laju benda terdapat fluida

\section{Persamaan Kontinuitas}

Persamaan kontinuitas menyatakan hubungan antara kecepatan fluida yang masuk pada suatu pipa terhadap kecepatan fluida yang keluar. Hubungan tersebut dinyatakan dengan (Frits Dietzel \& Dakso Sriyonoa. 1980):

$$
\mathrm{Q}=\mathrm{A}_{1} \mathrm{v}_{1}=\mathrm{A}_{2} \mathrm{v}_{2}
$$

Dimana:

$\mathrm{A}_{1}=$ Luas penampang pipa $1\left(\mathrm{~m}^{2}\right)$

$\mathrm{A}_{2}=$ Luas penampang pipa $2\left(\mathrm{~m}^{2}\right)$

$\mathrm{v}_{1}=$ Kecepatan fluida pada pipa $1(\mathrm{~m} / \mathrm{s})$

$\mathrm{v}_{2}=$ Kecepatan fluida pada pipa $2(\mathrm{~m} / \mathrm{s})$

Debit adalah besaran yang
menyatakan volume fluida yang mengalir tiap satuan waktu:

$$
Q=\frac{V}{t}
$$

$$
\text { Dimana: } \begin{aligned}
\mathrm{Q} & =\text { debit air }\left(\mathrm{m}^{3} / \mathrm{s}\right) \\
\mathrm{V} & =\operatorname{volume}\left(\mathrm{m}^{3}\right) \\
\mathrm{t} & =\text { waktu }(\mathrm{s})
\end{aligned}
$$

\section{a. Tip Speed Ratio}

Tip speed ratio (rasio kecepatan ujung) adalah rasio kecepatan ujung rotor terhadap kecepatan angin bebas. Untuk kecepatan angin nominal yang tertentu, tip speed ratio akan berpengaruh pada kecepatan putar rotor. Turbin angin tipe lift akan memiliki tip speed ratio yang relatif lebih besar dibandingkan dengan turbin angin tipe drag. Tipe speed ratio dihitung dengan persamaan (Soeripno MS, 2009) :

$$
\lambda=\frac{\pi D n}{v 60}
$$

keterangan:

$$
\begin{aligned}
& \lambda=\text { tipe speed ratio } \\
& \mathrm{D}=\text { diameter rotor }(\mathrm{m}) \\
& \mathrm{n}=\text { putaran rotor }(\mathrm{rpm}) \\
& \mathrm{v}=\operatorname{kecepatan} \text { angin }(\mathrm{m} / \mathrm{s})
\end{aligned}
$$

\section{METODE PENELITIAN}

Pada proses Penelitian ini akan dilakukan di Laboratorium Fakultas Teknik UPS Tegal. mulai bulan April sampai bulan Juli 2013 dengan variabel bebas penelitian adalah kecepatan angin serta variabel terikat head atau tekanan pompa air. Metode yang digunakan dalam penelitian ini adalah metode eksperimen untuk mendapatkan parameter data berupa daya output, data tersebut diperoleh dari kecepatan putar turbin angin yang bervariasi. Alat dan bahan meliputi turbin air, pompa sentrifugal, 
pipa paralon ukuran $3 / 4$ inchi, sambungan pipa lurus, lem paralon, Gergaji potong, Stopwatch, Tabung ukur fluida (air) $250 \mathrm{ml}$, Thermometer, Manometer U, Jangka sorong, kemudian dilanjutkan Proses pembuatan alat dan memasang pompa air sesuai dengan yang di rencanakan.

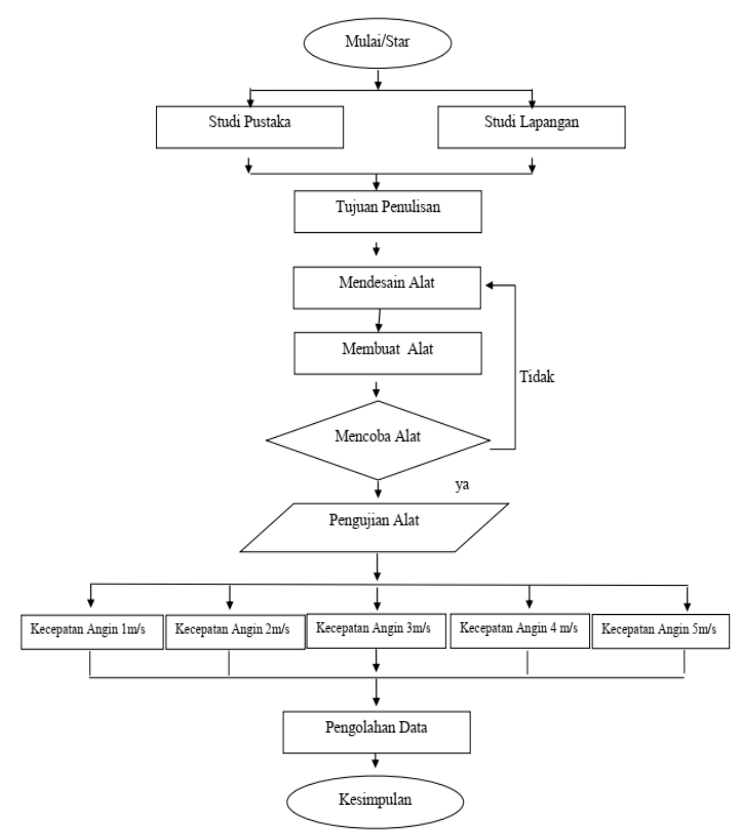

\section{Gambar 1. Rancangan Penelitian}

Teknik analisis data yang menggunakan Statistik Deskriptif yaitu statistik yang berfungsi untuk mendeskripsikan atau memberikan gambaran terhadap obyek yang diteliti melalui data sampel atau populasi sebagaimana adanya, tanpa melakukan analisis dan membuat kesimpulan yang berlaku untuk umum. Dalam penelitian ini data yang di dapat yaitu putaran poros turbin (rpm), kecepatan angin $(\mathrm{m} / \mathrm{s})$, temperatur lingkungan $\left({ }^{\circ} \mathrm{C}\right)$. Dimana data-data yang di dapatkan akan dihitung untuk mengetahui kemiringan sudut kemiringan dari sudut yang biasa menghasilkan daya maksimal untuk digunakan pada turbin angin vertical (Nur Utomo, 2008). Rumus dari hitungan-hitungan yang di gunakan tercantum dalam landasan teori.

\section{HASIL DAN PEMBAHASAN}

Pada pengujian daya turbin dapat dilihat pada Gambar 2. Dimana turbin angin poros vertikal terkena angin dengan kecepatan $1 \mathrm{~m} / \mathrm{s}$ dan $2 \mathrm{~m} / \mathrm{s}$ daya turbin angin tidak mengalami kenaikan signifikan yaitu 1,6 watt. Pada turbin angin poros vertikal yang terkena angin dengan kecepatan $3 \mathrm{~m} / \mathrm{s}$, daya turbin angin meningkat sekitar 5,8 watt. Sedangkan turbin angin poros vertikal yang terkena angin dengan kecepatan 4 $\mathrm{m} / \mathrm{s}$ terus meningkat yaitu sekitar 9,2 watt.

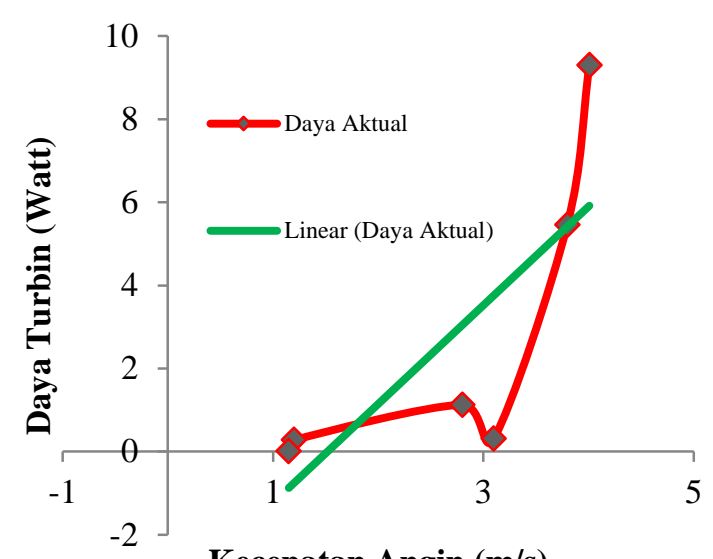

Kecepatan Angin (m/s)

\section{Gambar. 2 Grafik hubungan antara kecepatan angin dan daya turbin}

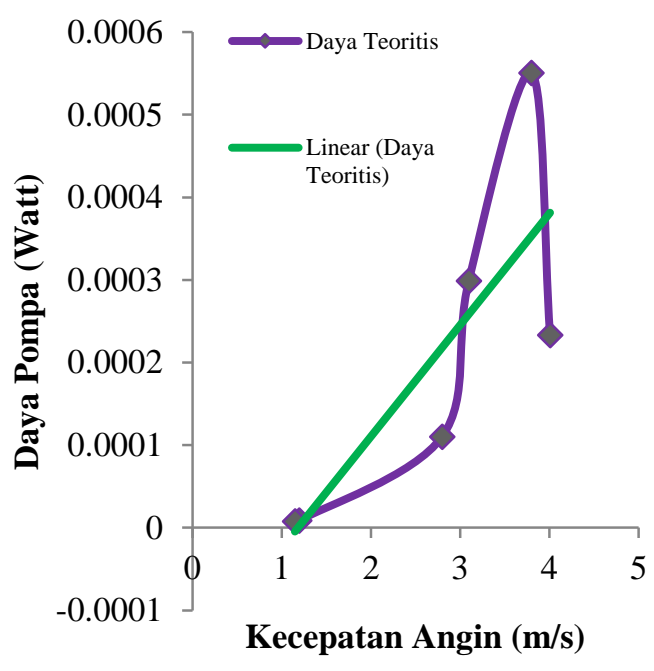

Gambar. 3 Grafik hubungan antara kecepatan angin dan daya pompa 


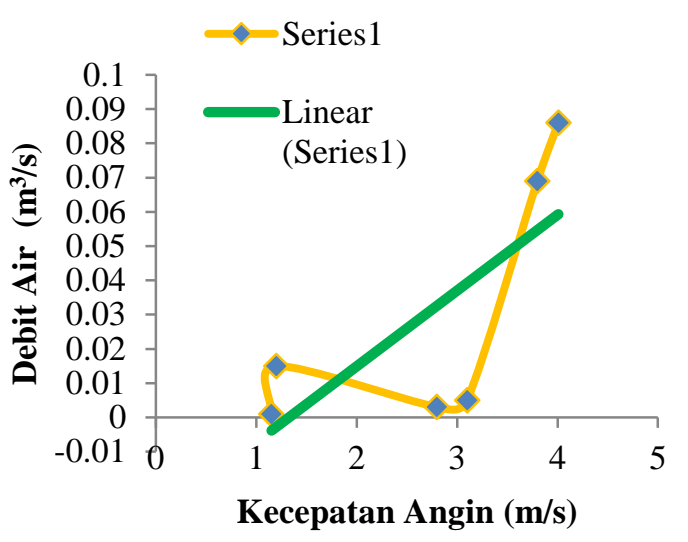

\section{Gambar. 4 Grafik hubungan antara kecepatan angin dan debit air}

Pada pengujian daya pompa dapat dilihat pada Gambar 3. Dimana turbin angin poros vertikal terkena angin dengan kecepatan $1 \mathrm{~m} / \mathrm{s}$ dan $2 \mathrm{~m} / \mathrm{s}$ daya teoretis tidak mengalami kenaikan signifikan yaitu 0,0001224 watt. Pada turbin angin poros vertikal yang terkena angin dengan kecepatan $3 \mathrm{~m} / \mathrm{s}$, daya teoretis meningkat mencapai 0,0005882 watt. Sedangkan pada turbin poros vertikal yang terkena angin dengan kecepatan $4 \mathrm{~m} / \mathrm{s}$ daya teoretis cenderung menurun yaitu 0,0002334 watt.

Pada pengujian debit air dapat dilihat pada Gambar 4. Dimana turbin angin poros vertikal terkena angin dengan kecepatan $1 \mathrm{~m} / \mathrm{s}$ debit air yang dihasilkan yaitu $0,018 \mathrm{~m}^{3} / \mathrm{s}$, pada kecepatan $2 \mathrm{~m} / \mathrm{s}$ debit air cenderung menurun yaitu $0,0035 \mathrm{~m}^{3} / \mathrm{s}$. Pada turbin angin poros vertikal yang terkena angin dengan kecepatan 3 $\mathrm{m} / \mathrm{s}$, debit air meningkat mencapai $0,068 \mathrm{~m}^{3} / \mathrm{s}$. Sedangkan pada turbin poros vertikal yang terkena angin dengan kecepatan $4 \mathrm{~m} / \mathrm{s}$ debit air semakin meningkat yaitu mencapai $0,086 \mathrm{~m}^{3} / \mathrm{s}$.

\section{KESIMPULAN}

Berdasarkan hasil pengolahan data yang di ambil maka disimpulkan bahwa : Daya terbesar turbin angin poros vertikal yaitu 9,2 watt yang menghasilkan debit air sekitar $0,086 \mathrm{~m}^{3} / \mathrm{s}$, dengan daya teoretis 0,0002334 watt. Turbin angin poros vertikal dapat berputar kecepatan angin yang rata-rata $3 \mathrm{~m} / \mathrm{s}$, debit air yang maksimum dari pengujian kecepatan angin 1 $\mathrm{m} / \mathrm{s}-4 \mathrm{~m} / \mathrm{s}$ diperoleh debit air yang paling tinggi.

\section{DAFTAR PUSTAKA}

Clup, Archie W. (1991), "Principles of Energy Conversion. New York: McGraw-Hill

Daryanto, Y. (2007). Kajian Potensi Angin untuk Pembangkit Listrik Tenaga Bayu. Yogyakarta: Balai PPTAGG -UPTLAGG.

Frits Dietzel \& Dakso Sriyonoa. (1980), " Turbin Pompa \& Kompresor". Jakarta. Erlangga

Nakajima, M., Lio, S., \& Ikeda, T. (2008). Performance of Double-step Savonius Rotor for Environmentally Friendly Hidroulic Turbine. Journal of Fluid Science And Technology, 3 (3), 410-419.

Nugroho, A., Sinaga, N., \& Haryanto, I. (2018). Performance of A Compression Ignition Engine Four Strokes Four Cylinders On Dual Fuel (Diesel-LPG). AIP Conference Proceedings, 2014. https://doi.org/10.1063/1.5054570

Nur Utomo. (2008). “ Desain Kincir Angin Penggerak Pompa Air". Halueloe. Kendari

Soeripno MS. (2009). “ Sistem Konversi Energi Angin Menjadi Energi Mekanik Dan Listrik". Lapan. Bogor

Victor dan Benjamin. (1999), Mekanika Fluida, Erlangga, Jakarta. 